\title{
A New Species of Hexathrombium Cooreman, 1944 Based on Parasitic Larva on Erotylids from Brazil (Acari: Eutrombidiidae)
}

\author{
Ryszard Haitlinger \\ Department of Zoology, Academy of Agriculture, ul. Cybulskiego 20, 50-205 Wroclaw, Poland
}

Hexathrombium abirami n. sp. (Acari: Eutrombidiidae) an ectoparasite larvae of Erotylidae (Coleoptera) from Brazil is described. A key to larval Hexathrombium is given.

Key words: Acari - Eutrombidiidae - Hexathrombium abirami - new species - Erotylidae - Brazil

The genus Hexathrombium was created for a species $H$. spatuliferum from Zaire by Cooreman (1944). Long before the species Trombidium cicindelae was described from French Guiana by Floch and Abonnec (1941). According to Fain and Drugmand (1993) this species also belongs to the genus Hexathrombium. Two other species belonging to this genus are: H. fageli Fain and Drugmand (1993) from Ivory Coast and Ethiopia and $H$. willisi Southcott (1993) from USA (Oklahoma). Haitlinger (1994) decribed four new species of the genus Beronium Southcott. Three of them in unison with differential diagnosis, given by Southcott (1993), also belong to the genus Hexathrombium (B. marittae Haitlinger from Chile, B. lubomirae Haitlinger from Sumatra and Madagascar and $B$. sorayae Haitlinger from China). To date the genus Hexathrombium comprises eight species (along with a new species). All these species (as larvae) are associated with Coleoptera, especially with Cicindellidae (H. cicindelae, H. willisi), Carabidae (H. spatuliferum, $H$. marittae, $H$. sorayae, $H$. lubomirae), Staphylinidae (H. fageli) and Erotylidae (H. abirami n. sp.). The species of the Hexathrombium at present are known from Neotropical, Nearctic, Afrotropical and Indoaustralian Regions.

\section{MATERIALS AND METHODS}

The examined specimens of Hexathrombium abirami n. sp. were obtained from the collection of Erotylidae (Coleoptera) in the Museum of Natural History, Wroclaw University (MNHWU). Holotype and two paratypes are deposited in MNHWU; further three paratypes are in authors collection in Department of Zoology, Academy of Agriculture, Wroclaw.

Received 6 May 1996

Accepted 19 August 1996
Measurements are expressed in micrometers. For the terminology of setae and other morphological characters used, see Southcott (1993).

\section{EUTROMBIDIIDAE Thor, 1935 \\ Hexathrombium abirami $\mathrm{n}$. sp.}

(Figs 1-8)

Description - Mite with an elongate idiosoma. Scutum as in Fig. 7 bears short setae PL (AL in all specimens are broken), AM short and thin (maybe their distal part is damaged); sensillae relatively thin, damaged. Setae PL placed somewhat below bases of sensillae. Scutalae PL slightly barbed. One pair of eyes is present at posterolateral margins of scutum (Fig. 1). The first scutellum is longer and wider than the remaining ones. It bears two setae (in all specimens damaged); they are set in middle of shield (between anterior and posterior margins). Also scutella II and III bear two setae each; these setae are slightly barbed. Setae on scutellum III are shifted to its anterior margin. These setae and setae set near all scutella are somewhat longer than lateral setae. Pygidial plate divided. Setae on this shields and two posterior setae on ventral side of idiosoma are longer than the remaining ones. Their distal part is barbed (Fig. 1). Whole area of scutum is covered by cuticular striae.

Ventrum also covered by cuticular striae. Between coxae III are two small setae. Beyond coxae III are 14 setae. Among them two lateral setae are thick and barbed, two pygidial setae are relatively long; the remaining ones are spiniform (Fig. 2).

Gnathosoma not clearly seen. Mouth-ring with a number of radial sucker markings (Fig. 3). Palpal tibial claw short with two, blunted tines. Palptarsus with eight nude setae; among them two are long (Fig. 8).

Leg lengths (including coxae, excluding claws): I - 290 in holotype, 301, 303, 284 in paratypes, II 258, 258, 244, 254, III - 240, 228, -, 228. Lateral coxala I flatened, slightly bifid; medial coxala I slender, spiniform. Lateral coxalae II and III as 

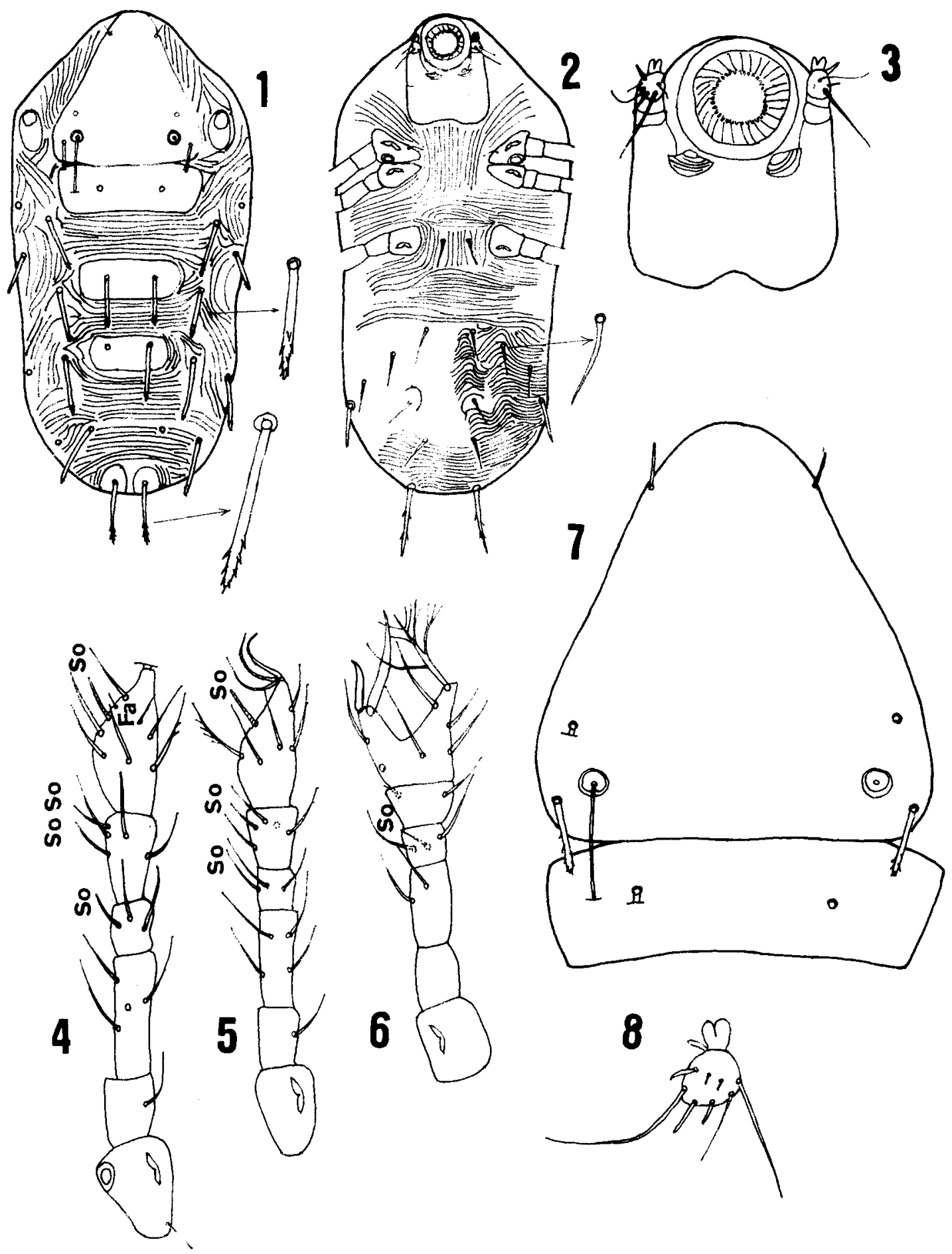

Hexathrombium abirami n. sp. Fig. 1: idiosoma, dorsal view. Fig. 2: idiosoma, ventral view. Fig. 3: gnathosoma, ventral view. Fig. 4: leg I, tarsus - coxa. Fig. 5: leg II, tarsus - coxa. Fig. 6: leg III, tarsus - coxa. Fig. 7: scutum and scutellum. Fig. 8: palptarsus. 
coxalae I. Urstigma small, oval.

Leg specialized setae. Leg I. Ta - 1 So, ! Fa; Ti - 2 So; Ge - 1 So. II. Ta - 1 So; Ti - 1 So; Ge - 1 So. III. Ge - 1 So (Figs 4-6).

Leg trochanteralae $1,1,1$, femoralae 5,5,4, genualae $5,5 . ? 3$, tibialae $8,7,5$, tarsalae $14 \mathrm{~N}, 1 \mathrm{~B} ; 13 \mathrm{~N}, 3 \mathrm{~B}$; $5 \mathrm{~N}, 4 \mathrm{~B}$. Metric data of holotype and paratypes are given in Table.

Material: holotype larva, five paratype larvae. Host: undetermined Erotylidae (Coleoptera). Locality: unknown in Brazil.

Remarks: $H$. abirami n. sp. differs from $H$. cicindelae (Floch and Abonnec) by shorter Ta I, II and length of legs I,II (calculated basing on figures given by these authors). Differentiate features from other species are given below in a key.

TABLE

Metric data for Hexathrombium abirami n. sp.

\begin{tabular}{lrcllc}
\hline Character & $\begin{array}{c}\text { Holo- } \\
\text { type }\end{array}$ & $\begin{array}{c}\text { Para- } \\
\text { type }\end{array}$ & Character & $\begin{array}{c}\text { Holo- Para- } \\
\text { type }\end{array}$ \\
\hline $\begin{array}{l}\text { Length of } \\
\text { body }\end{array}$ & 640 & $712-808$ & PSW V & $30 \times 2$ & - \\
Width of & & & & & \\
body & 304 & $400-424$ & L V & 22 & - \\
L & 208 & $196-208$ & PLN V & 12 & - \\
W & 192 & $186-200$ & QW V & 40 & $34-40$ \\
AW & $\sim 150$ & $146-154$ & QL V & 80 & $92-98$ \\
PW & 174 & $172-182$ & TaI (L) & 72 & $70-76$ \\
AMB & 90 & $86-88$ & TaI (H) & 30 & $28-30$ \\
AP & 44 & $46-54$ & TiI & 36 & $38-42$ \\
MA & 108 & $98-100$ & GeI & 26 & $22-26$ \\
LN & 42 & $40-44$ & FeI & 56 & $50-56$ \\
ASB & 192 & $176-184$ & TrI & 40 & $40-46$ \\
PSB & 28 & $24-30$ & CxI & 60 & $60-65$ \\
AM & $\sim 16$ & $\sim 16-20$ & TaII (L) & 56 & $52-56$ \\
PL & 34 & 32 & TaII (H) & 30 & 25 \\
SB & 132 & $134-142$ & TiII & 32 & $32-34$ \\
SA & 36 & $36-42$ & GeII & 20 & $20-22$ \\
DS & $50-80$ & $34-98$ & FeII & 46 & $40-48$ \\
GL & 124 & $100-108$ & TrII & 44 & $38-42$ \\
PSW II & 180 & $184-200$ & CxII & 60 & $56-66$ \\
PSL II & 70 & 68 & TaIII (L) & 44 & $44-46$ \\
PLN II & 28 & 26 & TiIII & 28 & $24-26$ \\
\hline
\end{tabular}

\section{KEY FOR SPECIES DETERMINATION *}

1. Coxalae I-II with rounded lobes, not widely divergent H. willisi Southcott, USA Oklahoma

-. Coxalae I-II with pointed lobes, widely divergent .. 2.

2. Setae QL5 over 100 long, pygidial plate not divided, QW4 over 75

.... H. lubomirae (Haitlinger), Sumatra, Madagascar

-. Setae QL5 below 100, pygidial plate divided, QW below 75

3. PW below 135, QL below 54, SB below 105

..H. fageli Fain and Drugmand, Ivory Coast, Ethiopia

-. PW over 135, QL over 54, SB over 105 .................... 4.

4. QL5 over 78 5.

-. QL5 below 76 6.

5. AP below 38, PL below 24

H. sorayae (Haitlinger), China

-. AP over 42, PL over 28 ........ H. abirami n. sp., Brazil

6. QL5 over 65, AP below 50, MA over 84 H. spatuliferum Cooreman, Zaire -.QL5 below 65, AP over 54, MA below 84 . H. marittae (Haitlinger), Chile

* H. cicindelae (Floch and Abonnec) is not keyed on account of lack of measurements.

\section{ACKNOWLEDGMENT}

To Dr M Kak, Museum of Natural History, Wroclaw University, for the loan of the specimens.

\section{REFERENCES}

Cooreman J 1944. Notes et observations sur les acariens III. Bull Mus roy d'hist nat Belg 20: 1-16.

Fain A, Drugmand D 1993. Notes on the genus Hexathrombium Cooreman, 1944 (Acari Trombidiidae) with description of a new tribe and species from Afrotropical Staphylinidae (Coleoptera). Bull Ann r belge Ent 124: 121-128.

Haitlinger R 1994. Four new larval mites (Acari: Trombidiidae: Eutrombidiinae) ectoparasitic on carabids (Insecta: Coleoptera: Carabidae). Rev Chil Ent 21: 47-56.

Southcott RV 1993. Revision of the Taxonomy of the Larvae of the subfamily Eutrombidiinae (Acarina: Microtrombidiidae). Invert Tax 7: 885-959. 
